\title{
Role of Variety and Fertilizer Practices on Cowpeas (Vigna unguiculata) Yield and Field Incidence of the Parasitic Weed Alectra vogelii (Benth) in Central Malawi
}

\author{
Vernon H. Kabambe ${ }^{1} \&$ James M. Bokosi ${ }^{1}$ \\ ${ }^{1}$ Lilongwe University of Agriculture and Natural Resources, Lilongwe, Malawi \\ Correspondence: Vernon H. Kabambe, Lilongwe University of Agriculture and Natural Resources, P.O. Box 219, \\ Lilongwe, Malawi. E-mail: kabambev@gmail.com
}

Received: August 9, 2020

Accepted: September 24, 2020

Online Published: October 15, 2020

doi:10.5539/jas.v12n11p200

URL: https://doi.org/10.5539/jas.v12n11p200

\begin{abstract}
Grain legumes are an important component of the food systems in Malawi. The parasitic legume witchweed species Alectra vogelii (Benth) is among the problem pests with serious infestations in groundnuts (Arachis hypogea), soybeans (Glycine max), cowpeas (Vigna unguiculata) and other legumes. A study was conducted in 2013/14 and '14/15 seasons to evaluate the effects of three cowpea varieties (IT82E-16, Sudan 1 and Alectra-resistant Mkanakaufi) and fertilizer practices (no fertilizer applied, $5 \mathrm{t} \mathrm{ha}^{-1}$ cattle manure and $100 \mathrm{~kg} \mathrm{ha}^{-1}$ of inorganic 23:21:0+4S on cowpea grain yield, yield components and Alectra emergence at three sites in central Malawi. Cowpea grain yields ranged $400-2400 \mathrm{~kg} \mathrm{ha}^{-1}$. There were significant $(\mathrm{P}<0.05)$ variety effects on yield in 4 of 6 site-years, with variety IT82-16 consistently giving the highest yields (range 1200-2400 kg ha ${ }^{-1}$ ). There were significant variety effects on $A$. vogelii emergence with Mkanakaufiti having no Alectra throughout. Application of cattle manure strongly suppressed A. vogelii in 6 site-years all at 60 days after planting, while inorganic fertilizer suppressed Alectra in 3 of the 6 site-years. Cattle significantly but marginally (about $250 \mathrm{~kg}$ ha $^{-1}$ ) increased yield in 2 of the 6 site-years. The results show potential to suppress $A$. vogelii with cattle manure application. However, further studies are required to understand the causes of the limited yield response under manure or fertilizer application to make the practices attractive to farmers. More variety improvement studies to produce a range of varieties with better local adaptability and response to fertility amendments are recommended.
\end{abstract}

\section{Introduction}

Maize (Zea mays L.) is the staple food and predominant crop in the farming systems in Malawi. Grain legumes are also important and complement cereals in terms of nutrition and rotation benefits. In 2013/14 season grain legumes (pulses and groundnuts [Arachis hypogea]) were grown on a total $0.98 \mathrm{M}$ ha or $65 \%$ of the maize land (MoAFS, 2012). The relatively large area of grain legumes offers opportunity for complementary integration of maize and legumes in cropping systems. Grain legumes cropping systems are complimentary to staple cereals in many ways. Legumes are important for their enrichment of soil nitrogen through biological nitrogen fixation (Nyemba \& Dakora, 2010; Ojiem et al., 2000, Myaka et al., 2006), high protein content, edible oil, and animal feed. In Malawi, legumes have been widely promoted most notably through including the national Farm Input Subsidy Programme (FISP), which included seeds of grain legumes (MoAFS, 2007; Dorward et al., 2011; MoAIWD, 2012). Among the legumes, cowpeas (Vigna unguiculata) are one of the important crops for similar reasons. Cowpeas contain 22-32\% protein (Neil et al., 1992), are adaptable to drought (Hall, 2004), can be used as animal fodder, and have suitability as cover crops in conservation agriculture systems (Mupangwa et al., 2012). In Burkina Faso, Bado et al. (2006) reported that cowpeas accumulated 2.5-3.4 $\mathrm{t} \mathrm{ha}^{-1}$ of stover containing 50 to $115 \mathrm{~kg} \mathrm{ha}^{-1} \mathrm{~N}$ of which $52-56 \%$ was derived from the atmosphere while in Malawi, Magulu and Kabambe (2013) reported 1.5 to $3 \mathrm{t} \mathrm{ha}^{-1}$ of cowpea stover with $2.4 \% \mathrm{~N}$ content.

Among other production constraints, many legumes are prone to attack by the parasitic weed species Alectra vogelii of the family Orobanchaceae, which causes serious losses. The weed has been reported in many parts of Malawi (Riches \& Shaxson, 1993; Kabambe et al., 2014; CABI, 2017). Yield losses of up to $15-100 \%$ have been reported in groundnut, soybean (Glycine max) and bambara (Vigna subterranea L.) (Lagoke, 1989; Beck, 1989; Kureh et al., 1999). For cowpeas, Lagoke et al. (1993) reported yield losses of 41\%, while Riches (1989) 
reported losses of 80-100 in a susceptible cultivar in Botswana. In Tanzania, Mbwaga et al. (2000) reported yield losses of $50 \%$.

In Malawi Striga asiatica, another parasitic weed of the same family is also a serious constraint in the staple cereal maize, such that many fields experience the two species simultaneously. There have been extensive reviews on control methods on these witchweeds (Parker \& Riches, 1993; Parker, 2012; Rubiales \& Fernanez-Aparcio, 2012; Joel et al., 2013). Some of the control approaches for the witchweed A. vogelii considered feasible for smallholder famers include use of trap crops such as dolichos bean (Lablab purpureus [L.] Sweet), cotton (Gossypium hirsutum L.), okra (Hibiscus esculentus L.), pea (Pisum sativum L.) and faba bean (Vicia faba L.) (Parker \& Riches, 1993). While a resistant cowpea variety was released in Malawi in 2010 (Mviha et al., 2011; Kabambe et al., 2014), this is only one step in integrated management. Several resistant varieties are needed to meet the various biotic and abiotic production constraints in addition to satisfying diverse end-user preferences. Non-variety management approaches are therefore equally required for integrated management. Karanja et al. (2012) reported that cattle manure at $5 \mathrm{t} \mathrm{ha}^{-1}$ suppressed A. vogelii and improved yield of cowpeas, but effects depended on cowpea variety. Akande et al. (2008) reported that complementary use of Ogun rock phosphate and cow dung increased yields of cowpea in Nigeria. Much research on fertility fertilizer application has been done in S. asiatica, which has similar biology to A. vogelii. For example, in Malawi, Kabambe (1991) reported that cattle manure and fertilizer application controlled Striga asiatica in maize. In $S$. asiatica, nitrogen is known to reduce germination and emergence through reduction of stimulant production by host (Raju et al., 1990; Okonkwo, 1991). The ammonium form of $\mathrm{N}$ is particularly injurious to Striga seeds and suppressive to germination and radical elongation (Pesch \& Pieterse, 1982; Okonkwo, 1991; Chechin \& Press, 1993; Eplee \& Norris, 1994). A study was therefore conducted in 20013-14 and 2014-15 seasons to evaluate the combined role of cowpea genotype and fertilizer practices (cattle manure and inorganic fertilizer application) on cowpea productivity and Alectra field emergence.

\section{Materials and Methods}

\subsection{Trial Design, Treatment Factors and Sites}

The field trial was a $3 \times 3$ factorial experiment with three varieties (IT82E-16, Sudan 1 and Mkanakaufiti) and

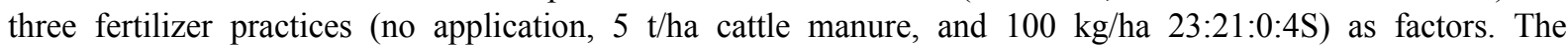
23:21:0:4S is a compound fertilizer available in Malawi and recommended for basal dressing in maize and soybeans, however, there is no fertilizer recommendation for cowpea production in Malawi (MoAFS, 2012). The purpose of the 23:21:0:4S treatment was to compare manure effects and an inorganic, non-ammonia source of fertilizer in common use. The $5 \mathrm{t} \mathrm{ha}^{-1}$ of manure has been shown to suppress Alectra and improve yields in cowpea (Karanja et al., 2012). The same rate has also been shown to improve yields in maize (Mloza-Banda \& Kabambe, 2014). The fertility amendments were studied using the application methods being used by farmers in order to evaluate the practice as a package. Varieties IT82E-16 and Sudan 1 are released, semi-erect with 59-74 days maturity period and yield potential of $2.0 \mathrm{t} \mathrm{ha}^{-1}$ (Mviha, 2011, MoAFS, 2012). Mkanakaufiti is also a released variety, resistant to $A$. vogelii, spreading type, 70-80 days maturity and yield potential of $2.3 \mathrm{t} \mathrm{ha}^{-1}$ (Kabambe et al., 2014; MoAFS, 2012). The trial sites were Bunda College, Mkwinda (near Bunda College, Lilongwe District) and Chioshya EPA in Mchinji in 2013-14 and Bunda, Chioshya and Mtunthama (Kasungu district) in 2014/15 season. All sites had a history Alectra vogelii pressure. The trial design was randomized complete block with four replicates at Bunda and 6 replicated on famers fields. A replicate was hosted on a separate farmers field. At each site the cattle manure was sourced from one famer but used by the rest of the farmers including at Bunda College where the manure came from the College farm. All sites are in the mid-altitude agro-ecological zone of Malawi with and mean annual rainfall of $875 \mathrm{~mm}$ (MoAFS, 2012). Table 1 gives the mean monthly rainfall planting and planting dates for the sites. The rainfall data for the Mkwinda is the same as for Bunda, as it was an on-farm site near Bunda. The rainfall in year one rainfall was in normal range while in year two of study rainfall was $50-60 \%$ lower than year average. 
Table 1. Mean monthly rainfall (mm), altitude (masl) and GPS for the trial sites in 2013/14 and 14/15 seasons

\begin{tabular}{|c|c|c|c|c|c|c|}
\hline & \multicolumn{3}{|c|}{ 2013/14 season } & \multicolumn{3}{|c|}{ 2014/15 season } \\
\hline & Bunda & Mkwinda & Chioshya & Bunda & Chioshya & Mtunthama \\
\hline Month/Planting date & 8.1 .14 & 20.1 .14 & 27.12 .13 & 5.1 .15 & 26.12 .14 & 3.12 .14 \\
\hline GPS & $\begin{array}{l}\text { S14.15035 } \\
\text { E33.78753 }\end{array}$ & $\begin{array}{l}\text { S14.15035 } \\
\text { E33.78753 }\end{array}$ & $\begin{array}{l}\mathrm{S} 13.7993^{\circ} \\
\mathrm{E} 33.1954^{\circ}\end{array}$ & $\begin{array}{l}\text { S14.15035 } \\
\text { E33.78753 }\end{array}$ & $\begin{array}{l}\mathrm{S} 13.7993^{\circ} \\
\mathrm{E} 33.1954^{\circ}\end{array}$ & $\begin{array}{l}\text { S14.7993ㅇ } \\
\text { E33.6346 }\end{array}$ \\
\hline Altitude masl & 1162 & 1128 & 1078 & 1162 & 1078 & 1165 \\
\hline October & 17.5 & 17.5 & 0 & 0 & 0 & 0 \\
\hline November & 39.3 & 39.3 & 0 & 28.4 & 8.2 & 42.4 \\
\hline December & 276 & 276 & 101.6 & 11.5 & 121.4 & 146 \\
\hline January & 273.8 & 273.8 & 330.6 & 226.9 & 138.1 & 156.4 \\
\hline February & 305 & 305 & 206.9 & 107.5 & 164.9 & 120.7 \\
\hline March & 132 & 132 & 90 & 103 & 122 & 67.5 \\
\hline April & 55.5 & 55.5 & 51 & 63.4 & 57 & 59.5 \\
\hline May & 5.5 & 5.5 & 0 & 18.9 & 0 & 21 \\
\hline Total & 1104.6 & 1104.6 & 780.1 & 549.2 & 611.6 & 613.1 \\
\hline
\end{tabular}

\subsection{Plots Sizes, Trial Management, Data Collected and Analysis}

The experimental crop was planted in plots of 4 with raised ridges each $4.0 \mathrm{~m}$ in length and $0.75 \mathrm{~m}$ apart. Two seeds of cowpeas were planted at $20 \mathrm{~cm}$ apart, giving an expected stand count of 13.3 plants $\mathrm{m}^{-2}$. The manure was applied in a band made by splitting the ridge to $20 \mathrm{~cm}$ depth and then rebuilding it, while the inorganic fertilizer was applied in a shallow band of $10 \mathrm{~cm}$ on the side of the ridge and covered. All cowpea or A.vogelii data was collected from the two middle rows giving a net plot size of $6 \mathrm{~m}^{2}$. Data collected for evaluation were cowpea grain yield (adjusted to $10.0 \%$ moisture), pod number, plant counts and $A$. vogelii counts. All insect and aphid pests were controlled by spraying according to recommendations (MoAFS, 2012). Data were analysed on site basis according to the analysis of variance procedure using the Genstat 16 package. Treatment effects were declared significant at $\mathrm{P} \leq 0.05$. Comparisons between means were done using the least significant difference, LSD at $\mathrm{t} \leq 0.05$.

\section{Results}

\subsection{Variety Effects on Cowpea Yield, Yield Components and Alectra Emergence}

In the 2013/14 season there were significant variety effects on cowpea harvest count (plants $\mathrm{m}^{-2}$ ) at Bunda only (Table 2) and not at Mkwinda (mean = 8.96) and Chioshya (mean =9.85). In the second season, significant variety effects on harvest count were observed at Bunda and Mtunthama (Table 2) and not at Chioshya (mean 12.78 plants $\mathrm{m}^{-2}$. There were also significant variety effects on pods plant ${ }^{-1}$ at Bunda (Table 1) and not Mkwinda (mean 5.79). Data for Chioshya was not available. In the second season, significant variety effects on pod plant ${ }^{-1}$ were observed also at Bunda only. Mean pod plant $^{-1}$ were 12.29 and 12.56 at Mtunthama and Chioshya, respectively. Mkanakaufiti generally performed poorly.

Table 2. Effect of variety on cowpea plant establishment and pods per plant at Bunda. Mtunthama and Chioshya, 2013/14 and 2014/15 season

\begin{tabular}{lllllll}
\hline \multirow{2}{*}{ Variety/Site/Season } & \multicolumn{3}{c}{ Plants at harvest $\mathrm{m}^{-2}$} & & \multicolumn{2}{c}{ Pods plant $^{-1}$} \\
\cline { 2 - 4 } \cline { 6 - 7 } & Bunda 2013/14 & Bunda 2014/15 & Mtunthama 2014/15 & & Bunda 2013/14 & Bunda 2014/15 \\
\hline IT82E-16 & 10.57 & 11.79 & 12.86 & & 9.59 & 20.28 \\
Sudan1 & 11.97 & 12.63 & 12.80 & & 10.96 & 20.73 \\
Mkanakaufiti & 12.85 & 13.04 & 11.80 & & 6.55 & 11.86 \\
Mean & 11.80 & 12.48 & 12.48 & & 9.03 & 17.62 \\
F prob & $<0.001$ & 0.026 & 0.006 & & 0.001 & 0.01 \\
LSD $_{0.05}$ & 1.01 & 0.89 & 0.70 & & 2.10 & 5.11 \\
\hline
\end{tabular}

The effects of cowpea variety on grain yield are shown in Table 3 . There were significant variety effects in 4 of the 6 site-years. No significant differences were observed in 2013/14 at Mkwinda (mean $679 \mathrm{~kg} \mathrm{ha}^{-1}$ ) and Chioshya (mean $2202 \mathrm{~kg} \mathrm{ha}^{-1}$ ). In all the cases Mkanakaufiti gave the lowest yields. High yields of 2000 to 2400 $\mathrm{kg} \mathrm{ha}^{-1}$ were observed at Mtunthama and Bunda in 2014/15. At all sites and in both seasons there were no 
significant differences of variety $\times$ fertilizer package interactions on cowpea data. Interestingly, yields in second year were about $2 \mathrm{t} \mathrm{ha}^{-1}$ and above, yet the season experienced low rainfall in the range 549 to $613 \mathrm{~mm}$.

There were significant cowpea variety effects on $A$. vogelii emergence effects at 40 and 60 days after planting at all sites (Tables 4 and 5). There was consistently no Alectra observed on Mkanakaufiti at 40 or 60 DAP. The results confirm the resistance of Mkanakaufiti to Alectra (Kabambe et al., 2014).

Table 3. Effect of variety cowpea grain yield $\mathrm{kg} \mathrm{ha}^{-1}$ in 2013/14 and 204/15 seasons

\begin{tabular}{lllll}
\hline \multirow{2}{*}{ Variety/Site } & \multicolumn{3}{c}{ Site and season } \\
\cline { 2 - 5 } & Bunda 2013/14 & Bunda $2014 / 15$ & Chioshya 2014/15 & Mtunthama 2014/15 \\
\hline IT82E-16 & 1203 & 2481 & 2186 & 2071 \\
Sudan 1 & 1413 & 2362 & 2002 & 2001 \\
Mkanakaufiti & 947 & 2068 & 1768 & 1676 \\
Mean & 1187 & 2304 & 1985 & 1916 \\
F prob & 0.007 & 0.010 & 0.007 & 0.009 \\
LSD $_{0.05}$ & 277 & 128 & 252 & 262 \\
\hline
\end{tabular}

Table 4. Effect of variety on Alectra counts at 40 and 60 days after planting (DAP) in 2013/14

\begin{tabular}{llllllll}
\hline \multirow{2}{*}{ Variety/Site } & \multicolumn{3}{c}{ Alectra counts $\mathrm{m}^{-2}-40$ days } & & \multicolumn{3}{c}{ Alectra counts $\mathrm{m}^{-2}-60$ days } \\
\cline { 2 - 3 } & Bunda & Mkwinda & Chioshya & & Bunda & Mkwinda & Chioshya \\
\hline IT82E-16 & 0.24 & 0.22 & 0.51 & & 1.78 & 1.58 & 2.18 \\
Sudan1 & 0.65 & 0.21 & 0.97 & & 2.12 & 1.79 & 2.79 \\
Mkanakaufiti & 0.0 & 0.0 & 0.0 & & 0.0 & 0.0 & 0.0 \\
Mean & 0.30 & 0.14 & 0.50 & & 1.30 & 1.13 & 1.66 \\
F prob & $<0.001$ & $<0.001$ & 0.07 & & 0.001 & $<0.001$ & $<0.001$ \\
LSD $_{0.05}$ & 0.33 & 0.12 & 0.84 & & 0.85 & 0.93 & 1.09 \\
\hline
\end{tabular}

Table 5. Effect of variety on Alectra counts at 40 and 60 days after planting (DAP) in 2014/15

\begin{tabular}{|c|c|c|c|c|c|c|}
\hline \multirow{2}{*}{ Variety/Site } & \multicolumn{3}{|c|}{ Alectra counts $\mathrm{m}^{-2} \_40$ days } & \multicolumn{3}{|c|}{ Alectra counts $\mathrm{m}^{-2}-60$ days } \\
\hline & Bunda & Chioshya & Mtunthama & Bunda & Chioshya & Mtunthama \\
\hline IT82E-16 & 0.5 & 0.93 & 1.2 & 2.01 & 5.5 & 3.6 \\
\hline Sudan1 & 0.9 & 1.03 & 1.1 & 2.07 & 6.2 & 4.6 \\
\hline Mkanakaufiti & 0 & 0.0 & 0 & 0 & 0 & 0 \\
\hline Mean & 0.4 & 6.65 & 0.74 & 1.4 & 3.9 & 2.7 \\
\hline F prob & $<0.001$ & $<0.001$ & $<0.001$ & $<0.001$ & $<0.001$ & $<0.001$ \\
\hline $\mathrm{LSD}_{0.05}$ & 0.15 & 0.39 & 0.48 & 0.41 & 2.4 & 0.014 \\
\hline
\end{tabular}

\subsection{Effects of Fertilizer Practices on Harvest Count, Pods Plant ${ }^{-1}$, Grain Yield and Alectra Emergence}

Fertilizer practice as factor did not significantly affect cowpea harvest count in both seasons except at Chioshya where manure application suppressed plant stand to 8.72 plants $\mathrm{m}^{-2}$ compared to 10.97 plants $\mathrm{m}^{-2}$ with no amendment. There were also fertilizer package effects on pods plant ${ }^{-1}$ only at Bunda in 2014/15. The inorganic fertilizer package of 23:21:0+4S had lowest pods plant $^{-1}$ of 15.4 , compared to 18.3 or 19.15 for no amendment and manure application. No significant interaction effects were observed.

The effects of fertilizer packages on grain yield are shown in Table 6 . There were significant fertilizer practice effects on yield in 3 of the 6 site-years. At Mkwinda (2013/14) and Mtunthama (2014/15) 20:21:0+4S gave the lowest yields. Notably cattle manure significantly increased yield at Mtumthama and Chioshya, even through by margins of only $250 \mathrm{~kg} \mathrm{ha}^{-1}$. 
Table 6. Effect of fertilizer package on cowpea grain yield $\left(\mathrm{kg} \mathrm{ha}^{-1}\right)$ in 2013/14 and 204/15 seasons

\begin{tabular}{llll}
\hline \multirow{2}{*}{ Fertilizer } & \multicolumn{3}{c}{ Site and season } \\
\cline { 2 - 4 } & Mkwinda 2013/14 & Mtunthama 2014/15 & Chioshya 2014/15 \\
\hline None & 698 & 1705 & 1764 \\
$5 \mathrm{t} \mathrm{ha}^{-1}$ cattle manure & 871 & 2001 & 2060 \\
$23: 21: 0+4 \mathrm{~S}\left(100 \mathrm{~kg} \mathrm{ha}^{-1}\right)$ & 468 & 1676 & 2131 \\
Mean & 679 & 1794 & 1985 \\
F Prob & 0.028 & 0.023 & 0.013 \\
LSD $_{0.05}$ & 290 & 262 & 252 \\
\hline
\end{tabular}

In 2013/14 att 40 DAP manure application significantly suppressed Alectra emergence at Mkwinda only. At 60 DAP manure application significantly suppressed Alectra numbers at all three sites. Alectra emergence (Table 7) was very low at 40 days after planting, DAP. In 2014/15 manure application significantly suppressed Alectra at all sites and counts (Table 8). It is also of interest to note that yields were highest at Chioshya, an on-farm site with high Alectra incidence.

Table 7. Effect of fertilizer package on Alectra counts at 40 and 60 days after planting (DAP) in 2013/14 season

\begin{tabular}{|c|c|c|c|c|c|c|}
\hline \multirow{2}{*}{ Fertilizer/Site } & \multicolumn{3}{|c|}{ Alectra counts $\mathrm{m}^{-2}-40$ days } & \multicolumn{3}{|c|}{ Alectra counts $^{-2}-60$ days } \\
\hline & Bunda & Mkwinda & Chioshya & Bunda & Mkwinda & Chioshya \\
\hline None & 0.38 & 0.32 & 0.54 & 1.69 & 2.17 & 2.54 \\
\hline $5 \mathrm{t} \mathrm{ha}^{-1}$ cattle manure & 0.29 & 0.04 & 0.54 & 0.36 & 0.18 & 0.53 \\
\hline $23: 21: 0+4 \mathrm{~S}\left(100 \mathrm{~kg} \mathrm{ha}^{-1}\right)$ & 0.22 & 0.07 & 0.40 & 1.85 & 1.04 & 1.86 \\
\hline F Prob & 0.61 & $<0.001$ & 0.93 & 0.002 & $<0.001$ & 0.02 \\
\hline LSD & 0.33 & 0.12 & 0.84 & 0.85 & 0.93 & 1.09 \\
\hline
\end{tabular}

Table 8. Effect of fertilizer package on Alectra counts at 40 and 60 days after planting (DAP) in 2014/15 season

\begin{tabular}{|c|c|c|c|c|c|c|}
\hline \multirow{2}{*}{ Fertilizer/Site } & \multicolumn{3}{|c|}{ Alectra counts $\mathrm{m}^{-2}-40$ days } & \multicolumn{3}{|c|}{ Alectra counts $^{-2}-60$ days } \\
\hline & Bunda & Chioshya & Mtunthama & Bunda & Chioshya & Mtunthama \\
\hline None & 0.6 & 0.82 & 1.1 & 2.2 & 5.9 & 4.3 \\
\hline $5 \mathrm{t} \mathrm{ha}^{-2}$ cattle manure & 0.2 & 0.25 & 0.1 & 0.5 & 1.1 & 0.8 \\
\hline $23: 21: 0+4 \mathrm{~S}\left(100 \mathrm{~kg} \mathrm{ha}^{-1}\right)$ & 0.4 & 0.85 & 1.0 & 1.5 & 4.8 & 3.2 \\
\hline F Prob & 0.029 & 0.009 & $<0.001$ & 0.002 & $<0.001$ & $<0.001$ \\
\hline LSD & 0.15 & 0.39 & 0.48 & 0.41 & 2.4 & 1.4 \\
\hline
\end{tabular}

There was significant variety $\times$ fertility amendment effect on Alectra emergence at 40 and 60 DAP at Mkwinda in 2013/14 and Mtunthama in 2014/15 (Table 9). In both cases the interaction is arising from non-emergence of Alectra at all fertilizer practices, and also the strong suppression of Alectra by manure across all varieties, while there was relatively high Alectra in the other varieties and fertilizer practices. The highlight of the results is that there was no Alectra emergence on Mkanakaufiti and strong suppression of Alectra by manure on all count dates in both seasons.

Table 9. Effect of variety $\times$ fertilizer package on Alectra emergence $\left(\mathrm{m}^{-2}\right)$ at 60 days after planting at Mkwinda (2013/14) and Mtunthama (2014/15)

\begin{tabular}{|c|c|c|c|c|c|c|}
\hline \multirow{2}{*}{ Variety/Fertilizer package } & \multicolumn{3}{|c|}{ Mkwinda 2013/14 } & \multicolumn{3}{|c|}{ Mtunthama 2014/15 } \\
\hline & No fertilizer & $5 \mathrm{t} \mathrm{ha}^{-1}$ manure & $100 \mathrm{~kg} \mathrm{ha}^{-1} 23: 21: 0$ & No fertilizer & $5 \mathrm{t} \mathrm{ha}^{-1}$ manure & $100 \mathrm{~kg} \mathrm{ha}^{-1} 23: 21: 0$ \\
\hline & --------------- & - & --o--octr & $\mathrm{nt} \mathrm{m}^{-2}$ & ------- & --------- \\
\hline IT82E-16 & 3.46 & 0.25 & 1.04 & 5.92 & 1.06 & 3.81 \\
\hline Sudan 1 & 3.0 & 0.2 & 2.08 & 7.0 & 1.19 & 5.64 \\
\hline Mkanakaufiti & 0.04 & 0 & 0 & 0 & 0 & 0 \\
\hline $\operatorname{LSD}(0.05)$ & 1.61 & & & 2.64 & & \\
\hline
\end{tabular}




\section{Discussion}

\subsection{How Does Alectra-Resistant Variety Maintain Its Resistance Without Yield Advantage?}

The yield ranges in the studies are similar to those of Kabambe et al. (2014) who reported yield ranges of 1-2.5 to tha- ${ }^{1}$ for the same varieties. The results show superiority in yield performance of the non-resistant varieties compared to the resistant varieties. The lack of yield advantage by Mkanakaufiti, while it demonstrated resistance to Alectra is disappointing, but consistent previous reports (Kabambe et al., 2014). Karanja et al. (2013) also showed that resistant germplasm to Alectra did not always give high yields, but provided source of germplasm for improvement. Genotype resistance remains an important trait in integrated management where it would serve to reduce Alectra seed build up in rotation systems as well as other non-variety interventions, which could include manure, mulching or herbicides. In a recent screen house study involving all three cowpea varieties with and without Alectra infection, (Phiri et al., 2018) reported no significant $(\mathrm{P}>0.05)$ variety or infection $\times$ variety interaction effect on cowpea root and shoot dry weight at 12 weeks, in support of these results whereby the resistance of Mkanakaufiti did not translate to better growth. However, in the same study, the authors reported significant Alectra inoculation and variety effect on dry root mass at 5 weeks only, which showed that infected cowpeas gave higher dry root mass and Mkanakaufiti gave the lowest root mass. Their results were attributed to weight of young Alectra plants on the roots of susceptible cowpea varieties. In a separate study, the authors reported that Mkanakaufi delayed but eventually supported germination of Alectra, suggesting refusal of further development as a mechanism. Previous studies have reported yields losses in cowpeas (Lagoke et al., 1993; Riches, 1989; Bagnall-Oakely et al., 1991) and other legumes (Lagoke, 1989; Beck, 1989; Kureh at al., 1999) thus it would be expected of resistant varieties to demonstrate a yield advantage especially under poor on-farm sites. Mugabe (1983) reported that yield in cowpea was mediated through delayed start of flowering, reduction in number of pods, and reduced mass of pods and grain. Alonge et al. (2001) reported the negative effects of Alectra on grain yield, grain protein content and total soluble carbohydrates depended on date of planting. This suggests that environmental factors such as water, temperature and soil fertility have part on the impact of Alectra. However, some varieties can be tolerant, as is likely with the two non-Alectra resistant varieties can be considered tolerant in view of repeated nature of results. A lack of variety $\times$ fertilizer interaction on grain yield in all site-years shows that while IT82E-16 is well adapted and high yielding, it is not responsive to fertility amendments. Hence breeding activities are required to develop genotypes that can respond to fertility improvements. At the time of its release, Mkanakaufiti was equal in yield to these varieties while possessing strong resistance.

\subsection{How Does Cattle Manure Suppress Alectra Without Consistent Yield Advantage?}

Alectra emergence was higher at $60 \mathrm{DAP}$ and the impact of fertilizer practices, particularly cattle manure, was more pronounced (Tables 7 and 8). The suppression of Alectra by cattle manure application conforms with many previous reports with Orobanchaceae family. In S. hermonthica or S. asiatica, which have similar host-parasite biology, nitrogen, particularly the ammonium form, has been reported to suppress germination and radicle elongation (Pesch \& Pieterse, 1982; Okonkwo 1991; Chechin \& Press, 1993; Eplee \& Norris, 1994). Use of both organic and inorganic fertilizer amendments has been reported to increase yields in cereals and cowpeas (Kabambe, 1991; Karanja et al., 2012; Akande et al., 2008). In this study fertilizer package effects were inconsistent, with significant effects observed in three of the six site-years (Table 6). The variation in yield advantage in study is thus not surprising. In cowpea Karanja et al. (2012) showed that that manure application increased yield of some varieties, and not others. Further, there is no fertilizer or manure recommendation for improved cowpea production in Malawi, suggesting responses to fertility amendments are rare. Farmers are therefore unlikely to take up manure application for the sake of Alectra control alone, calling for need to explore innovative cropping systems which include crops that can benefit from the fertility amendments in association or subsequent crops with cowpeas. Further studies are required to understand the specific reasons for lack of yield response to manure and $\mathrm{P}$ containing fertilizer, considering literature elsewhere which recommends fertility amendments. For example, Vanderborght and Baudin (2001) recommended P fertilization to increase cowpea yields at an N:P:K ratio of 1:2:1.

\section{Conclusion}

Alectra-resistant Mkanakaufiti remains strongly resistant while the two other released varieties showed good tolerance to Alectra. Breeding work should continue so that more varieties with diverse traits for famer and end-user preferences are available. The use of cattle manure at $5 \mathrm{t} \mathrm{ha}^{-1}$ had directive suppressive effects on Alectra emergence, with small and inconsistent yield benefits. The combined suppression of Alectra through genotype resistance and manure would form a strong base for reducing Alectra seed build in the soil in its integrated 
management. More germplasm should be evaluated to come up with varieties that can respond to fertility amendments hence provide incentive for famer adoption.

\section{Acknowledgements}

The authors are grateful to the McKnight Foundation of USA for financial support for this work. We thank management of Lilongwe University of Agriculture and Natural Resources for smooth facilitation of financial access and to all staff in the Department of Crop and Soil Sciences for technical assistance. We also that all staff and farmers in the sites for their excellent collaboration in the studies.

\section{References}

Akande, M. O., Oluwatoyimbo, F. I., Koyade, C. O., \& Olowokere, F. A. (2008). Response of maize (Zea mays) and okra (Abelmoschus esculentus) intercrop relayed with cowpea (Vigna unguiculata) to different levels of cow dung amended rock phosphate. African Journal of Biotechnology, 7(17), 3039-3043.

Alonge, S. O., Lagoke, S. T. O., \& Ajakaiye, C. O. (2001). Cowpea reactions to Alectra vogelii II: effect on yield and and nutrient composition. Crop Protection, 20(4), 291-296. https://doi.org/10.1016/SO261-2194(00) 00143-5

Bado, B. V., Batiano, A., \& Cescas, M. P. (2006). Assessment of cowpea and groundnut contributions to soil fertility and succeeding sorghum yields in the Guinea savannah zone of Burkina Faso. Biol. Fertil. Soils, 43, 171-176. https://doi.org/1007/s00374-006-0076-7

Bagnall-Okakely, H., Gibberd, V., \& Nyonges, T. E. (1991). The incidence and control A. vogelii in Embu district, Kenya. In J. K. Ransom, L. J. Musselman, A. D. Worsham, \& C. Parker, (eds). Proceedings of the $5^{\text {th }}$ International Symposium on Parasitic Weeds. CIMMYT, Nairobi, Kenya.

Beck, B. D. W. (1989). The effect of Alectra vogelii Benth. on the yield of njugo beans (Vigna subterranea (L.) Verdc.). In H. Chr. Weber, \& W. Forstreuter (Eds.), Parasitic Flowering Plants (pp. 79-82). Phillips University, Marburg, Germany.

CABI (CAB International). (2017). Invasive Species Compendium. Alectra vogelii (Yellow witchweed). Wellingford, CAB International. Retrieved from https://www.cabi.org/isc/datasheet/4234

Cechin, I., \& Press, M. C. (1993). Nitrogen relations of sorghum-Striga hermonthica host-parasite association: germination, attachment and early growth. New Phytologist, 124, 681-687. https://doi.org/10.1111/ j.1469-8137.1993.tb03858.x

Dorward, A., Chirwa, E, \& Jayne, T. S. (2011). Malawi Agricultural Input Subsidy Program Experience Over 2005-09. In P. Chuhan-Pole, \& M. Angawafo (Eds.), Yes Africa Can: Success Stories from a Dynamic Continent (pp. 289-318). Washington DC: The World Bank.

Eplee, R. E., \& Norris, R. S. (1994). Effect of N on parasitic weed seed. In: Pieterse AH, Verkleij JAC, ter Borg SJ. Biology and management of Orobanche. Proceedings of the Third International Workshop on Orobanche and related Striga research, Amsterdam, Netherlands (pp. 526-533). Royal Tropical Institute, Amsterdam, Netherlands.

Hall, A. E. (2004). Breeding for adaptation to drought and heat in cowpea. Europ. J. Agronomy, 21, $447-454$. https://doi.org/10.1016/j.eja.2004.07.005

Joel, D. M., Gressll, J., \& Musselman, L. J. (2013). Parasitic Orobancheae. Parasitic mechanisms and control strategies. Springer eBook. https://doi.org/10.1007/978-3-642-38146-1

Kabambe, V. H. (1991). The development of cultural control methods for control of Striga in maize in Malawi. In J. K. Ransom, L. J. Musselman, A. D. Worsham \& C. Parker (Eds.), Proceedings, $5^{\text {th }}$ International Symposium of Parasitic Weeds (pp. 46-50). Nairobi, CIMMYT.

Kabambe, V. H., Katunga, L., Kapewa, T., \& Ngwira, A. R. (2008). Screening legumes for integrated management of witchweeds (Alectra vogelii and Striga asiatica) in Malawi. African Journal of Agricultural Research, 3(10), 706-713.

Kabambe, V. H., Mazuma, E. D. L., Bokosi, J., \& Kazila, E. (2014). Release of cowpea line IT99K-494-6 for yield and resistance to the parasitic weed Alectra vogelii (Benth) in Malawi. African Journal of Plant Science, 8(4), 196-203. https://doi.org/10.5897/AJPS2013.1132 
Karanja, S., Nguluu, S. N., \& Gatcheru, M. (2012). Farm yard manure reduces the virulence of Alectra vogelii (Benth) on cowpea (Vigna unguiculata). African Journal of Plant Science, 6, 130-136. https://doi.org/ 10.5897/AJPS11.269

Karanja, S., Nguluu, S. N., Wambua, J., \& Gatcheru, M. (2013). Response of cowpea genotypes to Alectra vogelii parasitism in Kenya. African Journal of Biotechnology, 12(47), 6591-6598. https://doi.org/10.5897/ AJB12.1920

Kureh, I., Katunga, P. D., \& Orakwue, F. C. (1999). Reaction of soybean varieties to preconditioning and concentration of seed inoculum of Alectra vogelii (Benth). Science Forum. J. Pure Appl. Sci., 2(1), 116-124.

Lagoke, S. T. O. (1989). Striga in Nigeria. In T. O. Robson, \& H. R. Broad (Eds.), Striga Improved Management in Africa. FAO Plant Production and Protection Paper No. 96 (pp. 68-73). FAO, Rome, Italy.

Lagoke, S. T. O., Shebayan, J. Y., \& Magani, I. (1993). Striga problem and control in Nigeria. Paper presented at the Third General Workshop of Pan African Striga Control Network, Harare, Zimbabwe.

Mafongoya, P. L., Bationo, A., Kihara, J., \& Waswa, B. S. (2006). Appropriate technologies to replenish soil fertility in southern Africa. Nutr Cycl Agroecosyst, 76, 137-151. https://doi.org/10.1007/s10705-006-9049-3

Magulu, K., \& Kabambe, V. H. (2015). Evaluation of some elite lines for biomass, nodulation and yield. African Journal of Agricultural Research, 10(25), 2480-2485. https://doi.org/10.5897/AJAR2014.9123

Mbwaga, A. M., Kaswende, J., \& Shayo, E. (2000). A reference manual on Striga distribution and control in Tanzania. Kilosa, Tanzania: Ilonga Agricultural Research Institute.

Mloza-Banda, C., \& Kabambe, V. H. (2014). Agronomic evaluation of cattle manure and inorganic applications on maize yield at Bunda College, Lilongwe, Malawi. In V. H. Kabambe, Y. Tembo, \& A. Ngwira (Eds.), Proceedings of the first Integrated Soil Fertility Management symposium held at Sunbird Lilongwe Hotel. Lilongwe University of Agriculture and Natural Resources, Bunda College Campus, Lilongwe, Malawi.

MoAFS (Ministry of Agriculture and Food Security). (2007). Annual Agricultural Statistical Bulletin. Planning Division, Government of Malawi, Lilongwe, Malawi.

MoAFS (Ministry of Agriculture and Food Security). (2012). Guide to Agriculture Production in Malawi. Ministry of Agriculture and Food Security, Lilongwe, Malawi.

MoAIWD (Ministry of Agriculture, Irrigation and Water Development). (2012). Annual Agricultural Statistical Bulletin. Planning Division, Government of Malawi, Lilongwe, Malawi.

Mugabe, N. R. (1983). Effect of Alectra vogelii (Benth.) on cowpea (Vigna unguiculata (L.) i. Some aspects on reproduction of cowpea. Zimbabwe J. Agric. Res., 21, 135-147.

Mupangwa, W., Tromlow, S., \& Walker, S. (2012). Reduced tillage, mulching and rotational effects on maize (Zea mays L.) cowpea (Vigna unguiculata [Walp] L.) and sorghum under semi-arid conditions. Field Crops Research, 132, 139-148. https://doi.org/10.1016/j.fcr.2012.02.020

Mviha, P. J. Z., Mtukuso, A. P., \& Banda, M. H. P. (2011). A catalogue of agricultural technologies used by farmers in Malawi (p. 40). Department of Agricultural Research Services, Lilongwe, Malawi.

Myaka, F. M., Sakala, W. D., Adu-Gyamfi, J. J., Kamalongo, D., Ngwira, A., Odgaard, R., ... Hegh-Jensen, H. (2006). Yields and accumulations of $\mathrm{N}$ and $\mathrm{P}$ in farmer-managed intercrops of maize-pigeonpea in semi-arid Africa. Plant and Soil, 285, 207-220. https://doi.org/10,1007/s11104-006-9006-6

Neil, F. S., Siebrits, F. K., \& Hayes, J. P. (1992). Nutritive value of cowpeas (Vigna unguiculata) South African Journal of Animal Science, 22(5), 157-160.

Nyemba, R. C., \& Dakora, F. D. (2010). Evaluating $\mathrm{N}_{2}$ fixation by food grain legumes in farmers' fields in three agro-ecological zones of Zambia, using N15 natural abundance. Bio Fertl Soils, 46, 461-470. https://doi.org/10.10.1007/s00374-010-0451-2

Ojiem, J. O., Vanlauwe, B., de Ridder, N., \& Giller, K. E. (2000). Niche-based assessment of contribution of legumes to nitrogen economy of Western Kenya smallholder farm. Plant Soil, 292, 119-135. https://doi.org/10.1007/s11104-007-9207-7

Okonkwo, S. N. C. (1991). In vitro growth response of cultured and germinated seeds of witchweed (Striga asiatica). In J. K. Ransom, L. J. Musselman, A. D. Worsham, C. Parker (Eds.), Proceedings of the 5th International Symposium of Parasitic Weeds, June 24-30, 1991 (pp. 155-163). Nairobi: International Maize and Wheat Improvement Centre (CIMMYT). 
Parker, C. (2012). Parasitic weeds. A World Challenge. Weed Science, 60(2), 269-276. https://doi.org/10.1614/ WS-D-11-00068.1

Parker, C., \& Riches, C. R. (1993). Parasitic Weeds of the World. Biology and Control (p. 332). CAB International, Oxon, UK. https://doi.org/10.1017/s0890037x00039003

Pesch, C., \& Pieterse, A. H. (1982). Inhibition of germination of Striga by means of urea. Experiencia, 38, 599-560. https://doi.org/10.1007/BF02327047

Phiri, C. K., Kabambe, V. H., Bokosi, V., \& Mumba, P. (2018). Screening for resistance mechansisms in cowpea genotypes on Alectra vogelii. American Journal of Plant Science, 9, 1362-1379. https://doi.org/10.4236/ ajps.2018.96099

Raju, P. S., Osman, M. A., Soman, P., \& Peacock, J. M. (1990). Effects of N and P on Striga asiatica (L.) Kuntze seed germination and infestation on sorghum. Weed Research, 30, 139-144. https://doi.org/10.1111/ j.1365-3180.1990.tb01697.x

Riches, C. R. (1989). Alectra vogelii Benth.-constraint to cowpea production in southern Africa. In M. A. Mgomja, (Ed). Striga Research in spouthern Africa and strategies for regionalized control options. International Crops Research Institute for Semi-Arid Tropics.

Riches, C. R., \& Shaxson, L. J. (1993). In D. C. Munthali, J. D. T. Kumwenda, \& F. Kisyombe (Eds.), Parasitic weed problems in southern Malawi and use of farmer knowledge in the design of control measures (pp. 165-174). Conference on Agricultural Research for Development organised by the Soil Pests Project (University of Malawi) and the Malawi Maize Research Team, Ministry of Agriculture, June 7-11, 1993, Mangochi, Malawi.

Rubiales, D., \& Fernadez-Aparicio, M. (2012). Innovations in parasitic weeds management in legume crops: A review. Agron Sustain. Dev., 32, 433-449. https://doi.org/10.1007/s13593-011-0045-x

Vanderborght, T., \& Baudin, J. P. (2001). Cowpea Vigna unguiculata (L.) Walpers. In R. H. Raemaekers (Ed.), Crop Production in Tropical Africa (pp. 334-348). Directorate General for International Co-operation, Ministry of Foreign Affairs, External Trade and International Co-operation, Brussels, Belgium.

\section{Copyrights}

Copyright for this article is retained by the author(s), with first publication rights granted to the journal.

This is an open-access article distributed under the terms and conditions of the Creative Commons Attribution license (http://creativecommons.org/licenses/by/4.0/). 